\title{
Wybrane cechy rozwoju języka u dzieci z niepełnosprawnością wzroku
}

\begin{abstract}
Izabella Kucharczyk, Wybrane cechy rozwoju języka u dzieci z niepetnosprawnościa wzroku [Selected features of language development in children with visually impaired]. Interdyscyplinarne Konteksty Pedagogiki Specjalnej, nr 14, Poznań 2016. Pp. 89-113. Adam Mickiewicz University Press. ISSN 2300-391X

This review of research literature presents the difficulties encountered by blind children at individual developmental stages of speech. This report aims to appraise recent peer reviewed literature relating to communication and language development in children with VI. The language and communication developmental characteristics may assist speech-language therapists to build a knowledge base for participation in early intervention for young children with visual impairment.
\end{abstract}

KEY WORDS: children with visually impaired; communication, speech, delays in the acquisition of verbal skills

\section{Wprowadzenie}

Człowiek jako jedyne żyjące stworzenie na ziemi posiada umiejętność komunikowania się za pomocą języka. Mimo że zwierzęta komunikują się ze sobą za pomocą nawoływań czy nieartykułowanych dźwięków, nie przekazują sobie informacji odnoszących się do faktów, mitów czy historii danej rodziny. Język ludzki jest bardzo elastyczny, np. małe dzieci potrafią z kilku nieartykułowanych dźwięków utworzyć zdanie z zakodowaną informacją. Dzięki językowi 
człowiek może przekazywać myśli, interpretować fakty, a także wymieniać się poglądami z innymi. Bez języka nie można byłoby pisać książek, tworzyć opowiadań ani rozmawiać.

Język jest „wynalazkiem” bardzo złożonym. Daje możliwość tworzenia kultury, ale jest także efektem działania tej kultury. Za jego pośrednictwem rozwija się cywilizacja, w której żyjemy. Język pełni także funkcję społeczną. Jest niczym innym jak pewnym systemem, który ma za zadanie łączyć ze sobą symbole (m.in. słowa), ale $\mathrm{w}$ taki sposób, aby można było $\mathrm{z}$ nich utworzyć jak największą ilość różnych stwierdzeń służących komunikacji. Wynika z tego także, że język jest bardzo ważnym aspektem myślenia ${ }^{1}$.

Aby dziecko mogło sprawnie posługiwać się językiem, potrzebne są mu dwie kompetencje: językowa i komunikacyjna. Ta pierwsza dotyczy znajomości budowy i reguł niezbędnych do tworzenia języka. To wiedza nieuświadomiona, zapewniająca tworzenie właściwych (dla danego języka) zdań, a odrzucanie tych, które są zbudowane niepoprawnie. Kompetencja owa jest niezbędna do tego, aby móc porozumiewać się $\mathrm{z}$ innymi ${ }^{2}$. Z kolei druga kompetencja (komunikacyjna) dotyczy wiedzy, która wykorzystywana jest podczas rozmowy w celu dostosowania własnych komunikatów do rozmówcy i porozumienie się z nim³ $^{3}$.

Jak wyżej stwierdzono, język służy do komunikacji. Wyjaśnienie tego pojęcia nastręcza pewne trudności. Wynika to przede wszystkim z faktu nadużywania i nadinterpretacji czasownika „komunikować"4. Zdaniem Włodzimierza Głodkowskiego ${ }^{5}$ przyczyny nale-

1 S.K. Ciccarelli, J.N. White, Psychologia, Dom Wydawniczy Rebis, Poznań 2015; D.R. Schaffer, K. Kipp, Psychologia rozwoju. Od dziecka do dorostości, Wydawnictwo Harmonia, Gdańsk 2015.

2 . N. Chomsky, Zagadnienia teorii składni, Zakład Narodowy Ossolińskich, Wrocław, Warszawa, Kraków, Gdańsk, Łódź 1982.

3 J. Porayski-Pomsta, O rozwoju mowy dziecka. Dwa stadia, Dom Wydawniczy ELIPSA, Warszawa 2015; J. Porayski-Pomsta, Umiejętności komunikacyjne i językowe dzieci w wieku przedszkolnym, Wydawnictwo UW, Warszawa 1993.

4 T.J. Clevenger, Can One Not Communicate? A Conflict of Models?, "Communication Studies" 1991, 42, s. 340-353, za: E. Kulczycki, Teoretyzowanie komunikacji, Wydawnictwo Naukowe Instytutu Filozofii UAM, Poznań 2012. 
ży upatrywać w 1) braku analizy samego słowa "komunikacja”, 2) szerokości zjawiska oraz 3) wykorzystania tego pojęcia (nie zawsze adekwatnie) w prawie każdej dziedzinie wiedzy.

Francis A. Cartier i Kenneth A. Harwood ${ }^{6}$ w oparciu o analizę artykułów zebranych w "Journal of Communication" wyróżnili cztery grupy definicji pojęcia komunikacja. Do pierwszej zaliczyli definicje deskryptywne mające na celu przedstawienie praktycznego aspektu procesu komunikacji, ale bez uwzględniania wszystkich jego składników. Druga grupa to definicje normatywne, czyli takie, które wyjaśniają, czym komunikacja powinna być. Trzecia - to definicje o charakterze intuicyjnym, czyli takie, których zadaniem jest próba konstruowania pytań dotyczących komunikacji. Do ostatniej grupy zaliczono definicje funkcjonalne, których celem jest ustalenie funkcji i zadań komunikacji.

Jak twierdzi Bogusława Dorobek-Ostrowska7, komunikacja jest procesem społecznym, gdyż muszą w nim uczestniczyć co najmniej dwie osoby, przebiega $\mathrm{w}$ określonym kontekście społecznym, jest ciągła, dynamiczna, celowa i świadoma, nieodwracalna oraz nieuchronna (komunikacja będzie zawsze zachodzić ze względu na jej uświadomiony oraz nieuświadomiony charakter).

W literaturze przedmiotu można znaleźć wiele modeli aktów komunikacyjnych. Do najbardziej znanych należą m.in.: model aktu perswazyjnego Harolda Lasswella8; model przekazu sygnałów Claude`a E. Shannona i Weaver Weavera, model wspólnoty doświadczeń Schramma, model percepcji George`a Gerbnera, modele

${ }^{5}$ W. Głodkowski, Komunikowanie interpersonalne, Hansa Communication, Warszawa 2006.

${ }^{6}$ F.A. Cartier i K.A. Harwood, On Definition of Communication, "Journal of Communcation” 1953, 3(2), s. 71-75, za: E. Kulczycki, op. cit.

${ }^{7}$ B. Dorobek-Ostrowska, Podstawy komunikowania społecznego, Wydawnictwo ASTRUM, Wrocław 2004.

${ }^{8}$ Zob. H. Lasswell, The Structure and Fuction of Communication in Society, [w:] L. Bryson, The communication of ideas, Cooper Square Publishers, New York 1948, za: J. Fiske, Wprowadzenie do badań nad komunikowaniem, Wydawnictwo ASTRUM, Wrocław 1999. 
przepływów informacji, model trójkątny Theodore`a M. Newcom$\mathrm{ba}^{9}$, modele komunikacyjne semiotyczne m.in. model lingwistyczny Romana Jacobsona ${ }^{10}$. Na omówienie zasługują dwa ostatnie. Model trójkątny T. Newcomba11 oparty jest na założeniu, że zarówno odbiorca, jak i nadawca mogą pełnić jednocześnie dwie funkcje i nadawcy, i odbiorcy. Jeden i drugi może zarówno wydawać komunikat, jak i go odbierać. Nadawca i odbiorca nie działają indywidualnie. Są uzależnieni od środowiska społecznego, gdyż to ono kształtuje zachowania i umożliwia modyfikację tego zachowania poprzez dostosowanie się do zmiany.

$\mathrm{Z}$ kolei model lingwistyczny R. Jacobsona jest połączeniem modelu trójkątnego i linearnego. Cechą typową dla linearnego modelu jest relacja nadawca (funkcja ekspresyjna), komunikat (funkcja poetycka), adresat (funkcja konatywna). Natomiast pozostałe elementy tworzą trójkąt, a są nimi: kontekst (funkcja odniesienia; każdy komunikat musi być przekazany w odpowiednich warunkach, aby był prawidłowo odczytany i zrozumiany); kontakt (funkcja fatyczna; odnosi się on zarówno do kontaktu fizycznego, jak i psychicznego między nadawcą a odbiorcą); kod (funkcja metajęzykowa, czyli system wspólnych znaków za pomocą których przekazywana jest informacja). Modele te zakładają, że bez wyżej wymienionych, charakterystycznych dla poszczególnych modeli elementów, nie zajdzie proces komunikacji. To, jaki model wybierze dana

${ }^{9}$ C.E. Shannon, WWeaver, Mathematical Theory of Communication, University of Illions, Urbana 1948, za: T. Goban-Klas, Media i komunikowanie masowe. Teorie $i$ analizy prasy, radia, telewizji i Internetu, Wydawnictwo PWN, Warszawa 2001; W. Głodkowski, op. cit.; The Process and Effects of Mass Communication, red. W. Schramm, University of Illinois, Urbana 1954, za: T. Goban-Klas, op. cit.; G. Gerbner, Toward a general model of communication, "Audiovisual Communication Review" 1953, 4(3), s. 171-199; T.M. Newcomb, An approach to the study of communication acts, "Psychological Review" 1953, 60(6), p. 393-404, za: W. Głodkowski, op. cit. 1989.

${ }^{10} \mathrm{R}$. Jacobson, W poszukiwaniu istoty jezzyka, Wydawnictwo PIW, Warszawa

11 T.M. Newcomb, op. cit., za: T. Goban-Klas, op. cit.; W. Głodkowski, op. cit.: J. Fiske, op. cit. 
osoba, będzie decydować o sposobie komunikacji, ale też o odczytaniu zakodowanej informacji i odpowiedniej reakcji zwrotnej. Bez właściwie przebiegającego procesu komunikacji dziecko nie nauczy się danego języka lub będzie miało trudności i będzie popełniać błędy, a przełoży się to na niemożność zrozumienia interlokutora.

\section{Podstawowe elementy procesu komunikowania}

Niezależnie od tego, który model komunikacji jest omawiany, zawsze należy brać pod uwagę jego stałe, niezmienne elementy, do których zalicza się: nadawcę i odbiorcę, źródła komunikacji, przekazywane komunikaty, kanały, szumy, kontekst oraz sprzężenie zwrotne ${ }^{12}$. W niniejszym artykule omówię tylko te, które mają największe znaczenie w procesie komunikacji dzieci z niepełnosprawnością wzroku.

Kanały komunikacji mogą być dwojakiego rodzaju: werbalne i niewerbalne. Komunikacja werbalna to komunikacja za pomocą języka, czyli słów oraz za pomocą pisma13. Natomiast komunikacja niewerbalna to intencjonalne bądź nieintencjonalne wykorzystywanie naturalnych właściwości posiadanych zmysłów. Obejmuje ona mimikę ciała, ton głosu, gesty, pozycję ciała i jego ruchy, odgłosy nieartykułowane, oddech oraz dotyk ${ }^{14}$. Należy też zaznaczyć, że nie każda osoba potrafi prawidłowo odczytywać te komunikaty, co może powodować zwiększanie się zakłóceń w tym procesie.

Analizując proces komunikacji, nie można zapomnieć o tzw. szumach. W literaturze przedmiotu pojęcie to może odnosić się do

12 B. Dorobek-Ostrowska, op. cit.; J. Fiske, op. cit.; T. Goban-Klas, op. cit.; E. Kulczycki, op. cit.

${ }^{13}$ M.L. Knapp, J.A. Hall, Komunikacja niewerbalna w interakcjach międzyludzkich, Wydawnictwo ASTRUM, Wrocław 2000.

${ }^{14}$ E. Aronson, T.D. Wilson, R.M. Akert, Psychologia społeczna. Serce i umyst, Wydawnictwo PWN, Warszawa 2000; M.L. Knapp, J.A. Hall, op. cit. 
trzech grup: szumów wewnętrznych, zewnętrznych i semantycznych. Te pierwsze to m.in. pobudzenie emocjonalne, potrzeby fizjologiczne czy odczuwany np. ból. Druga grupa to szumy zewnętrzne i mogą być nimi: hałasy słyszane z zewnętrz, odczuwane zapachy, temperatura powietrza $\mathrm{w}$ pomieszczeniu, niestosowne ubranie, niewłaściwa ilość bodźców wzrokowych. Natomiast szum semantyczny dotyczy traktowania przez odbiorcę wszystkich zakodowanych informacji w zdaniu bardzo dosłownie np. „patrzeć przez palce”, „rzucić okiem”, „zjeść konia z kopytami” lub „marzenia ściętej głowy”. Dzieci lub dorośli, jeśli nie potrafią uwzględnić w komunikacie tego rodzaju szumu, będą w niewłaściwy sposób interpretować dany komunikat i zmieniać treść, jednocześnie modyfikując swoje zachowanie ${ }^{15}$.

Sprzężenie zwrotne to nic innego jak reakcja odbiorcy na odkodowany komunikat. Dzięki niemu nadawca może się zorientować, czy jego informacja została prawidłowo odczytana czy też nie ${ }^{16}$.

Wszystkie powyżej opisane składowe mają znaczenie w procesie przebiegu komunikacji międzyludzkiej. Są one niezwykle ważne w przypadku dzieci z niepełnosprawnością wzroku, gdyż bardzo często elementy te są nieprawidłowo interpretowane, a sam proces nabywania języka jest opóźniony lub występują różne zakłócenia.

\section{Rozwój języka i mowy}

Rozwój kompetencji językowych jest jedną z największych umiejętności dziecka w wieku poniemowlęcym. Jest dużym skokiem w rozwoju umożliwiającym poznawanie świata poprzez zadawanie pytań, rozumowanie, dokonywanie procesów dedukcji i indukcji, szukanie odpowiedzi i nawiązywanie relacji społecznych. Wszystkie te zdolności powodują, że dziecko nabiera bardzo szybkiego tempa rozwoju, zwłaszcza w sferze poznawczej.

15 B. Dorobek-Ostrowska, op. cit.; J. Fiske, op. cit.; T. Goban-Klas, op. cit.

16 W. Głodkowski, op. cit. 
Uczenie się języka ojczystego u każdego dziecka następuje według tego samego schematu - najpierw wypowiadane są wyrazy pojedyncze, potem zwroty dwuwyrazowe, a z czasem coraz bardziej złożone konstrukcje. Pomimo że ludzie posiadają tzw. instynkt językowy, nie znaczy to, że każdy człowiek rodzi się ze zdolnością mówienia i używania języka (pomimo ogromnych możliwości ludzkiego mózgu). Musi nauczyć się nie tylko reguł gramatycznych, ale przede wszystkim powinien zdobyć doświadczenie i trening w używaniu języka. Największy przyrost wiedzy i kompetencji językowej przypada na drugi, trzeci rok życia. Natomiast okresem krytycznym jest szósty, siódmy rok życia ${ }^{17}$.

Aby dziecko mogło nauczyć się mowy, musi być spełnionych kilka warunków. Pierwszym jest prawidłowo działający receptor słuchu (ucho wewnętrzne, zewnętrzne i środkowe), nerw słuchowy oraz kora słuchowa w lewym płacie skroniowym. Również dobrze działający ośrodek ruchowy Broca w płacie czołowym i ośrodek czuciowy Wernickego mają istotne znaczenie dla tego procesu. Okres, w którym rozwija się analizator słuchowy, to wiek prenatalny (mniej więcej od 12. tygodnia życia płodowego, kiedy powstają struny głosowe) i trwa do około 10. roku życia ${ }^{18}$. Aby człowiek mógł mówić, musi mieć rozwiniętą korę słuchową oraz przedczołową. Badania Mariny Budny, Davida Dodell-Federa, Alvaro Pascual-Leone, Eveliny Fedorenko ${ }^{19}$ pokazują, że obszary mózgu, które są odpowiedzialne za widzenie w przypadku braku możliwości korzystania ze wzroku, mogą przetwarzać dane dotyczące języka w wyniku zdobywania i poszerzania się wczesnych doświadczeń.

Zdaniem Barbary Bocus i Grace W. Shugar istnieje ścisła relacja pomiędzy percepcją a tworzeniem się mowy. W proces ten zaangażowany jest nie tylko zmysł słuchu, ale także wzroku. Obserwacja

${ }^{17}$ L. Eliot, Co tam się dzieje. Jak rozwijać mózg i umyst w pierwszych latach życia, Wydawnictwo Media Rodzina, Warszawa 2010.

18 B. Harwas-Napierała, J. Trempała, Psychologia rozwoju człowieka. Charakterystyka okresów życia człowieka, Wydawnictwo PWN, Warszawa 2001.

${ }^{19}$ M. Bedny, D. Dodell-Feder, A. Pascual-Leone, E. Fedorenko, Language processing in the occipital cortex of congenitally blind, "Proceedings of the National Academy of Science" 2011, nr 15; 108 (11), s. 4429-4434. 
przez dziecko ruchu ust osoby mówiącej powoduje nie tylko utrwalanie kodu z informacją wzrokowo-słuchową, lecz także angażuje pamięć i poprawia kodowanie. „Reprezentacja mowy u ludzi jest wielomodalna i właśnie taką postać przyjmuje ona we wczesnym okresie życia" 20 .

Warto pamiętać, że rozwój mowy i języka oraz rozwój motoryczny są ze sobą ściśle związane. Jeżeli obserwuje się u dziecka opóźnienia w zakresie rozwoju motoryki dużej i motoryki małej, to można spodziewać się opóźnień w zakresie mowy. Motoryka ma ogromne znaczenia dla somatognozji, planowania ruchowego, czynności samoobsługowych czy orientacji przestrzennej. Bez tych umiejętności dziecko będzie preferowało siedzący tryb życia. Takie dzieci potrzebują większej stymulacji ruchowej, proprioceptywnej, przedsionkowej i dotykowej. Zabawa różnymi przedmiotami powoduje, że dziecko wydaje najpierw nieartykułowane, a później artykułowane dźwięki ${ }^{21}$. Dodatkowo należy pamiętać o tym, że bliska lokalizacja ośrodków położonych w mózgu odpowiadających za przetwarzanie i wydawanie mowy (ośrodek Broca, pole 44 . w płacie czołowym) oraz kora somatosensoryczna są ze sobą ściśle związane. Stymulując dziecko pod kątem rozwoju motoryki małej, wpływamy na poprawę mowy22.

Jak twierdzi Miguel Perez-Pereira23, należy prowadzić badania dotyczące rozwoju mowy $\mathrm{u}$ osób $\mathrm{z}$ niepełnosprawnością wzroku z dwóch przyczyn. Po pierwsze im większa jest wiedza na ten temat, tym proces wczesnego wspomagania będzie efektywniejszy. Po drugie im naukowcy będą posiadać większą wiedzę na temat

${ }^{20}$ B. Bocus i G.W. Shugar, Psychologia języka dziecka. Osiagnięcia, nowe perspektywy, Wydawnictwo GWP, Gdańsk 2007, s. 54.

${ }^{21}$ J. Cieszyńska, Metoda Krakowska wobec zaburzeń rozwoju dzieci. Z perspektywy fenomenologii, neurobiologii $i$ językoznawstwa, Wydawnictwo Centrum Metody Krakowskiej, Kraków 2013.

22 T. Górska, A. Grabowska, J. Zagrodzka, Mózg a zachowanie, Wydawnictwo PWN, Warszawa 2000; K. Walsch, Neuropsychologia kliniczna, Wydawnictwo PWN, Warszawa 2000.

${ }^{23}$ M. Perez-Pereira, Language Development in Blind Children, [w:] Encyclopedia of Language and Linguistics, t. 6, red. K. Brown, Pergamon, Oxford 2000, s. 357-361. 
rozwoju mowy i nabywania kompetencji językowych u niewidomych i słabo widzących, tym teorie na ten temat będą bardziej rozbudowane i sprawdzone.

Przegląd literatury polskiej i anglojęzycznej, pedagogicznej, psychologicznej i logopedycznej pokazuje, że artykułów na temat uszkodzeń wzroku i jego wpływu na rozwój mowy u dzieci jest stosunkowo niewiele. Nie świadczy to jednak o tym, że zagadnienia tego nie poruszano wcale. Opisywano albo pojedyncze przypadki, albo tylko fragmenty badań, nie omawiając jednak dokładnie specyfiki rozwoju mowy u niewidomych.

W literaturze przedmiotu istnieją dwa stanowiska na temat wpływu braku zmysłu wzroku na rozwój mowy. Pierwsze to założenie, że dziecko z niepełnosprawnością wzrokową pod względem językowym będzie rozwijać się i przechodzić przez stadia rozwoju mowy tak samo jak dziecko widzące. Zdaniem Tadeusza Majewskiego ${ }^{24}$ dzieci niewidome rozwijają się fonetycznie oraz lingwistycznie jak dzieci widzące. Według autora do prawidłowego rozwoju mowy potrzebne są dobrze ukształtowany narząd mowy, narząd słuchu i kora mózgowa, prawidłowy ogólny stan zdrowia, odpowiedni poziom inteligencji i sprzyjające czynniki środowiskowe. Zatem gdy powyższe warunki zostaną spełnione, nie ma żadnych przeciwwskazań do prawidłowego rozwoju mowy u dzieci niewidomych. Wyniki tych badań zostały także potwierdzone przez m.in. przez Claire E. Wakefield, Judi Homewood i, Alana J. Taylor ${ }^{25}$ czy Marzennę Zaorską ${ }^{26}$. Zupełnie inaczej tę kwestię postrzega

24 T. Majewski, Tyflopsychologia rozwojowa. Psychologia dzieci niewidomych $i$ stabo widzacych, Polski Związek Niewidomych, Warszawa 2002.

25 Zob. C.E. Wakefield, J. Homewood, A.J. Taylor, Early blindness may be associated with changes in performance on verbal fluency tasks, "Journal of Visual Impairment \& Blindness" 2006, 100(5), s. 306-310, za: J. Konarska, Rozwój i wychowanie rehabilitujace dziecka niewidzącego w okresie wczesnego i średniego dzieciństwa, Wydawnictwo UP, Kraków 2010.

${ }^{26}$ M. Zaorska, Tyflologopedia jako subdyscyplina szczegótowa logopedii oraz element jej wspótczesnej koncepcji strukturalnej, „Przegląd Badań Edukacyjnych” 2016, nr 1 (22), s. 149-161; M. Zaorska, Istota i szczególność zaburzeń mowy oraz terapii logopedycznej dzieci z niepetnosprawnością wzrokowa, „Forum Logopedy” 2015, nr 7, s. 46-50. 
m.in. Antonii Pruszewicz27, który twierdzi, że uszkodzony wzrok wpływa na powstawanie opóźnień, a w niektórych przypadkach powoduje zaburzenia rozwoju mowy i języka. Jest on zdania, że gdy dziecko od momentu urodzenia jest pod wpływem permanentnego działania czynników stresogennych, w konsekwencji prowadzi to do potęgowania się trudności związanych $\mathrm{z}$ uczeniem się mowy. Po dziś dzień kwestia ta nie jest rozsądzona. Należałoby raczej analizować przebieg rozwoju mowy u niewidomych nie tyle pod kątem zaburzeń w rozwoju, co występowania charakterystycznych cech i przyjąć pogląd Bronisława Rocławkiego ${ }^{28}$, który uważa, że aby mogła rozwinąć się mowa, potrzebne jest współdziałanie trzech systemów sensorycznych: wzrokowego, słuchowego i dotykowego. Skoro u niewidomych pierwszy kanał jest nieczynny, to mowa tych dzieci przebiega w sposób specyficzny.

\section{Wybrane czynniki mające wpływ na rozwój mowy dzieci z niepełnosprawnością wzroku}

Pierwsze przejawy rozwoju mowy są czynnościami spontanicznymi, niemającymi związku z procesem uczenia się. We wczesnym etapie dziecko najczęściej ćwiczy struny głosowe, pojawia się głużenie (guganie, gruchanie), a następnie gaworzenie. Około pierwszego roku życia dziecko zaczyna wypowiadać słowa. Pod jego koniec słuch fonematyczny jest coraz lepiej ukształtowany i jest ćwiczony poprzez powtarzanie i odtwarzanie dźwięków.

27 A. Pruszewicz, Opóźniony rozwój mowy, [w:] Foniatria kliniczna, red. A. Pruszewicz, Wydawnictwo PZWL, Warszawa 1992, s. 233-241, za: S. Milewski, K. Kaczorowska-Bray, Logopedyczne aspekty przyswajania jezzyka przez dzieci niewidome. „Poradnik Językowy” 2015, nr 5, s. 31-44.

${ }^{28}$ B. Rocławki, Kształtowanie komunikacyjnych postaw u dzieci w wieku niemowlęcym, [w:] Opieka logopedyczna od poczecia, red. B. Rocławski, Wydawnictwo UG, Gdańsk 1989, s. 78-82, za: K. Kaczorowska-Bray, S. Milewski, Wczesna interwencja logopedyczna, Wydawnictwo HARMONIA, Gdańsk 2016. 
Wyniki badań w omawianej grupie dzieci są sprzeczne. Ewa Bendych i Maria Janik ${ }^{29}$ oraz David H. Warren ${ }^{30}$ twierdzą, że obserwacja osoby mówiącej nie jest podstawowym wyznacznikiem nauczenia się mówienia. Natomiast Michael Brambing czy Gunilla Preisler ${ }^{31}$ uważają, że opóźnienia mogą dotyczyć nawet trzech, czterech miesięcy. I tak wg M. Brambringa dzieci niewidome pierwsze słowa zaczynają wypowiadać dopiero około 16. miesiąca życia.

Wielu naukowców podkreśla znaczenie interakcji między rodzicami a dzieckiem. Michael Pérez-Pereira i Mariela Resches ${ }^{32}$ opublikowali badania mające na celu określenie poziomu nawiązywanych interakcji między sześcioma matkami i ich dziećmi z uszkodzonym wzrokiem (słabowidzącymi i niewidomymi) i ich wpływem na poziom kompetencji językowych. W pierwszym badaniu dzieci były obserwowane w czasie, gdy miały 28-34 miesiące, drugie badanie odbyło się, gdy ukończyły 35 miesięcy. Zwracano uwagę na pragmatyczne funkcje wypowiedzi językowych zarówno dzieci jak i ich matek. Okazało się, że matki dzieci niewidomych mówią do dzieci więcej, stosują więcej opisów, uwzględniając pragmatyczne aspekty mowy.

W kolejnych badaniach przedstawiających relacje między matkami i ich dziećmi z niepełnosprawnością wzroku również potwierdzone zostały powyższe wyniki, że matki dzieci niewidomych

${ }^{29}$ E. Bendych, M. Janik, Nauczanie początkowe dzieci niewidomych, Wydawnictwo PWN Warszawa 1981.

${ }^{30}$ D.H. Warren, Blindness and early childhood development, American Foundation for the Blind, Inc. New York 1977.

${ }^{31}$ M. Brambring, Lehrstunden eines blinden Kindes, Verlag, Munchen 2000, za: S. Milewski, K. Kaczorowska-Bray, op. cit.; G. Preisler, Communicative Development in Young Blind Children, [w:] Communcative Development, red. G. Conti-Ramsden, C. Snow, Cambridge University Press, Cambridge 1990, s. 130-152, za: K. Kaczorowska-Bray, S. Milewski, op. cit.; K. Jaworska-Biskup, Language acquisition in the blind child, Wydawnictwo KUL, Lublin 2011.

32 M. Pérez-Pereira, Análisis pragmático de las conversaciones entre niños ciegos y sus madres y la cuestión de la directividad maternal/Pragmatic analysis of conversations between blind children and their mothers and the issue of maternal directivity, "Infancia y Aprendizaje" 2008, nr 31(4), s. 425-447. 
mówią do nich co prawda więcej, lecz nie zawsze musi to mieć przełożenie na poziom ich sprawności językowej. Większość badań była przeprowadzona w warunkach domowych ${ }^{33}$.

Nie należy również zapominać, że wzrok dzieci jest zastępowany słuchem i dotykiem. Tadeusz Gałkowski ${ }^{34}$ podkreśla, że „u niemowląt niewidomych ewentualne opóźnienia w mowie mogą być spowodowane faktem, że słyszanym przez nie wypowiedziom pochodzącym od rodziców, rodzeństwa, domowników nie towarzyszą obrazy wzrokowe ruchów i układów ust podczas artykulacji". Z kolei Selma Freiberg ${ }^{35}$ zauważyła, że w przypadku niewidomych niemowląt charakterystyczna jest mniejsza liczba wokalizacji w przeciwieństwie do dzieci widzących. Jest to związane z tym, że nasłuchują one, kiedy rozmówca zaczyna coś do niech mówić, a nie koncentrują się na odpowiedzi.

W literaturze zarówno polskiej, jak i anglojęzycznej zwraca się uwagę na wpływ czynników wewnętrznych na rozwój języka dziecka już od momentu urodzenia się. Zalicza się do nich m.in. czynniki temperamentalne, charakter, umiejętności motoryczne itp. ${ }^{36}$. Nie wolno jednak zapominać, że istnieją jeszcze czynniki zewnętrzne (środowiskowe), które odgrywają ogromną rolę w procesie nabywania kompetencji językowych ${ }^{37}$. Do czynników tych można zaliczyć zjawi-

33 J. Campbell, Maternal directives to young children who are blind, "Journal of Visual Impairment and Blindness" 2003, 91. 355-365; G. Conti-Ramsden, M. PerezPereira, Conversational interactions between mothers and their infants who are congenitally blind, have low vision, or are sighted, "Journal of Visual Impairment and Blindness" 1999, 93, s. 691-703; L.S. Kekelis, P.M. Prinz, Blind and sighted children with their mothers: The development of discourse skills, "Journal of Visual Impairment and Blindness" 1996, nr 90, s. 423-436.

34 T. Gałkowski, Trudności rozwojowe u dzieci niewidomych w okresie niemowlęcym, „Przegląd Tyflologiczny” 1975, Nr 1/3, s. 8.

$35 \mathrm{~S}$. Freiberg, Insights from the blind: Comparative studies of blind and sighted infants. New American Library, New York 1977.

$36 \mathrm{~J}$. Dote-Kwan, M. Hughes, The home environments of young blind children, “Journal of Visual Impairment and Blindness" 1994, 88, s. 31-42.

37 A.J. Sameroff, B.H. Fiese, Transactional regulation: The developmental ecology of early intervention, [w]: Handbook of early childhood intervention, red. J.P. Shonkoff, S.J. Meisels, Cambridge University Press, Cambridge 2000, s. 135-159 
sko werbalizmu (tzw. pustosłowia) ${ }^{38}$. Zdaniem naukowców jest to bardzo niekorzystne zjawisko polegające na tym, że dzieci niewidome używają słów zawierających treści wzrokowe, nie zawsze rozumiejąc znaczenie danego wyrazu. Zjawisko to jest bardzo charakterystyczne dla dzieci w młodszym wieku szkolnym, natomiast $\mathrm{u}$ dzieci starszych występuje sporadycznie. Jego nasilenie zależy od poziomu inteligencji osoby niewidomej. Im poziom inteligencji jest większy, tym w mniejszym stopniu występuje zjawisko werbalizmu ${ }^{39}$. Aby go uniknąć, należy przekazywać wiedzę nie tylko w sposób słowny, ale także wykorzystywać modele przedstawiające omawiane zjawisko. W ten sposób dziecko dotykowo zdobywa wiedzę praktyczną, a jego wyobrażenia stają się bliższe rzeczywistości. Jeżeli dziecko pozna słowa bez rozumienia ich znaczenia, to może pojawić się tzw. „pustosłowie", co spowoduje, iż świat w którym żyje, będzie przez nie interpretowany nieadekwatnie ${ }^{40}$. Badania Annie Vinter, Viviane Fernandes, Oriana Orlandi i Pascal Morgan ${ }^{41}$ podkreślają częste występowanie zjawiska werbalizmu w grupie dzieci niewidomych. Autorzy przebadali 96 dzieci z niepełnosprawnością wzroku, w tym 44 było całkowicie niewidomych. Dzieci te były w wieku od 6 do 14 lat. Ich zadaniem było zdefiniowanie 10 słów oznaczających konkretne przedmioty ożywione lub nieożywione. Odpowiedzi podzielono na kilka kategorii: odniesienie do doświadczeń sensorycznych: dotykowych i słuchowych, odniesie do koloru, do analogii, do zdobytych doświadczeń, do funkcji przedmiotu. Okazało się, że pojęcia, które były wyjaśniane za pomocą odniesienia do koloru i światła, w przeważającym stopniu potęgowały występowanie zjawiska werbalizmu.

${ }^{38}$ N. Mikołajczak-Matyja, Definicje formułowane przez niewidomych $i$ widzacych jako przyczynek do rozważań nad zjawiskiem werbalizmu, Szkoła Specjalna 2011, nr 5, s. 325-336; G. Conti-Ramsden, M. Perez-Pereira, op. cit.

${ }^{39} \mathrm{~K}$. Klimasiński, Rola wyobrażeń przestrzennych w rozwoju myślenia dzieci niewidomych, PAN, Zakład Narodowy Ossolińskich, Wrocław - Warszawa - Kraków Gdańsk 1989.

40 T. Majewski, op. cit.

${ }^{41}$ A. Vinter, V. Fernandes, O. Orlandi, P. Morgan, Verbal definitions of familiar objects in blind children reflect their peculiar perceptual experience, "Child: care, health and development" 2012, nr 39(6), s. 856-863. 


\section{Zasób słownictwa dzieci niewidomych}

Zdaniem Zofii Sękowskiej rozwój słownika dzieci niewidomych możliwy jest tylko wtedy, gdy otrzymują one warunki eksplorowania i poznawania otoczenia za pomocą zmysłów. W przeciwnym razie poznawanie świata i rozwój języka będzie opóźniony.

Bardzo dokładnej analizy słownika dziecka na etapie wyrazu dokonała Nawoja Mikołajczak-Matyja ${ }^{42}$. Okazało się, że dzieci niewidome częściej używały pojęć odnoszących się do tych kategorii, które związane były z podejmowanymi przez nie czynnościami i praktycznym działaniem, a nie do kategorii ogólnych.

Z badań Moniki Orkan-Łęckiej43 wynika, że cechą charakterystyczną dzieci niewidomych dopiero co zaczynających mówić, są przedłużające się echolalie. Gdy trwają one zbyt długi czas, może to świadczyć o braku rozumienia znaczenia poszczególnych słów i zbyt małej ilości doświadczeń. Autorka również zwraca uwagę na problem $w$ rozumieniu używania zaimków, przyimków i występowaniu mowy egocentrycznej.

W literaturze światowej poruszającej zagadnienie nabywania języka przez dzieci z niepełnosprawnością wzroku wykazano stosunkowo niewielkie różnice ilościowe między tą właśnie grupą a dziećmi posługującymi się wzrokiem ${ }^{44}$. Mimo występujących

${ }^{42}$ N. Mikołajczak-Matyja, Hierarchiczna struktura leksykonu umystowego. Relacje semantyczne w leksykonie widzacych i niewidomych użytkowników jezzyka, Wydawnictwo Naukowe UAM, Poznań 2008.

${ }^{43}$ M. Orkan-Łęcka, Mama, tata, dziecko czyli o tym, jak uczyć małe niewidome dziecko w warunkach domowych, "Materiały Tyflologiczne" 2003, nr 14.

${ }^{44}$ A. Bigelow, Blindness. In B. Hopkins. The Cambridge encyclopedia of child development, Cambridge University Press, New York 2005, s. 409-413; M. Brambring, Divergente Entwicklung blinder und sehender Kinder in vier Entwicklungsbereichen [Divergent development in children who are blind or sighted: Four developmental domains], "Zeitschrif für Entwicklungspsychologie und Päddagogische Psychologie" 2005, nr 37, s. 173-183; M. Brambring, Sprachentwicklung blinder Kinder [Language development in children who are blind], [w:], Psycholinguistik: Ein internationales Handbuch, red. G. Rickheit, T. Herrmann, W. Deutsch, de Gruyter, Berlin 2005 s. 730-752; D.D. Hatton, D.B. Bailey, M.R. Burchinal, K.A. Ferrell, Development growth curves 
w początkowych miesiącach życia dużych różnic, dzieci z niepełnosprawnością wzroku szybko uczą się i minimalizują te rozbieżności. Z kolei różnice jakościowe między grupami są już znaczące i dotyczą przede wszystkim używania rzeczowników. Dzieci niewidome mają trudności z rozpoznawaniem i określaniem podobieństw między obiektami w obrębie jednej kategorii semantycznej. Badania Ann Bigelow ${ }^{45}$ pokazują, że np. dzieci niewidome znacznie rzadziej używają nazwy "zwierzęta” (8\%) w porównaniu do widzących $(20 \%)$, natomiast odwrotna jest sytuacja, kiedy należy użyć nazw przedmiotów codziennego użytku (22\% - niewidomi i 9\% - widzący rówieśnicy). Różnica wynika stąd, że zwierzęta są atrakcyjniejsze dla dzieci widzących - mogą się z nimi bawić i spędzają z nimi bardzo dużo czasu).

Badania w zakresie zdolności językowych i rozwoju słownictwa w grupie dzieci niewidomych prowadził również Michael Brambring46 (2007). Badania te miały charakter longitudinalny i dotyczyły dziesięciorga dzieci. Zastosowanym testem był Bielefeld Observation Scales, BOS-BLIND dla dzieci do lat sześciu. Jest to skala obserwacyjna zawierająca 600 itemów. Do badań tych autor wybrał 107, z czego 29 odnosiło się do umiejętności werbalnych. Okazało się, że dzieci niewidome potrafiły nazwać 80\% pokazywanych przedmiotów po określonym czasie nauki. Poza tym badania w zakresie mówienia pierwszych słów nie wykazały różnic istotnych statystycznie. Występujące różnice są nieznaczne i bardzo szybko kompensowane. Zdaniem autora, aby jeszcze bardziej zminimalizować różnice między obiema grupami, należy dzieci niewidome jak najwcześniej stymulować pod kątem rozwoju mowy.

of preschool children with vision impairments, "Child Development" 1997, nr 68, s. 788-806; S.M. Rogow, Communication and language: Issues and concerns. [w:] The Lighthouse handbook on vision impairment and vision rehabilitation, Vol. 1, red. B. Silverstone, M.A. Lang, B.P. Rosenthal, E.E. Faye, Oxford University Press, New York 2000, s. 395-408.

${ }^{45}$ A. Bigelow, op. cit.

${ }^{46}$ M. Brambring, Divergent Development of Verbal Skills in Children Who Are Blind or Sighted, “Journal of Visual Impairment and Blindnes" 2007, s. 749-769. 
Z kolei Val Tadić, Linda Pring, Naomi Dale ${ }^{47}$ prowadziły badania na grupie 15 uczniów niewidomych i 26 uczniach słabowidzacych. Uczniowie ci zostali przebadani skalą werbalną testu WISC R Wechslera i takimi podtestami jak Wiadomości, Podobieństwa, Arytmetyka, Słownik, Rozumienie oraz Powtarzanie Cyfr jako test zastępczy. Żadne zadanie nie miało charakteru wykonawczego. Użyto także The Clinical Evaluation of Language Fundamentals-3 (CELF-3), ale wybrano tylko te podtesty, w których do rozwiązania nie wykorzystuje się zmysłu wzroku. Wykorzystano również kwestionariusz The Children's Communication Checklist-2 (CCC-2) składający się z 70 pytań dotyczących zdolności językowych sprawdzających m.in. składnię, semantykę, występujące stereotypie językowe, wykorzystywanie kontekstu, komunikacji niewerbalnej, zainteresowanie, relacje społeczne oraz określono ogólny poziom znajomości języka, zatem nie tyle badano inteligencję krystalizowaną i rozumowanie płynne, co poszczególne składowe języka. Test ten często jest wykorzystywany do szukania zaburzeń w komunikacji. CELF-3 i CCC-2 były rozwiązywane przez rodziców dzieci. Z przeprowadzonych badań wynika, że dzieci niewidome osiągają znacząco niższe kompetencje językowe od swoich rówieśników, którzy posługują się wzrokiem. Dotyczy to przede wszystkim sytuacji, gdy należy użyć kompetencji społecznych oraz praktycznych. Niższe zdolności pragmatyczne w użyciu języka przez dzieci z niepełnosprawnością wzroku potwierdzają badania m.in. R. Peter Hobson i Martin Bishop oraz G.M. Preisler ${ }^{48}$. Zdaniem autorów badania polegające na wypełnianiu przez rodziców kwestionariuszy dotyczących trudności językowych ich dzieci są o wiele bardziej

47 V. Tadić, L. Pring, N. Dale, Are language and social communication intact in children with congenital visual impairment at school age?, "Child Psychology and Psychiatry" 2010, Nr 51, 6, s. 696-705.

${ }^{48}$ R.P. Hobson, M. Bishop, The pathogenesis of autism: Insights from congenital blindness, "Philosophical Transactions of the Royal Society of London Series B Biological Sciences" 2003, Nr 358, s. 335-344; G.M. Preisler, Early patterns of interaction between blind infants and their sighted mothers, "Child: Care, Health and Development" 1991, nr 17, s. 65-90. 
miarodajne niż przeprowadzanie wystandaryzowanego testu w warunkach laboratoryjnych.

W Polsce pierwszych badań nad słownikiem dzieci z niepełnosprawnością wzroku dokonała Zofia Sękowska. Stwierdziła, że słownik dzieci niewidomych jest ilościowo bogatszy od słownika badanych dzieci widzących. Taki wynik może być skutkiem długotrwałej i bardzo dobrej opieki wychowawczej nad tymi dziećmi. „Funkcjonalne użycie słowa jest środkiem aktywnego kierowania uwagi i procesów analizy, syntezy i abstrakcji, a więc umożliwia adekwatne poznanie, mimo zubożenia o elementy wizualne konkretno-zmysłowego poznania świata"49. Autorka udowodniła również, że w zakresie używania części mowy, czyli zastosowania rzeczowników, czasowników, liczebników itd. nie ma różnic między niewidomymi a widzącymi. Najważniejszym wnioskiem z badań jest stwierdzenie, że brak wzroku nie powoduje zubożenia słownika oraz nierozumienia stosowania złożonych form gramatycznych. Mowa pełni funkcję kompensacyjną. „Słowo mówione czy pisane kompensuje braki w poznaniu niewidomego dziecka, informując o niedostępnych dla jego bezpośredniego poznania zjawiskach przyrody, stosunkach, sytuacjach oraz zachodzących w przestrzeni i czasie" 50 .

Kwestią związaną z nabywaniem słownictwa i rozumieniem go jest zagadnienie występowania wyobrażeń surogatowych (zastępczych) u dzieci niewidomych ${ }^{51}$. Dotyczą one wyobrażeń tych zja-

${ }^{49}$ Z. Sękowska, Kształcenie dzieci niewidomych, Wydawnictwo PWN, Warszawa 1974 , s. 212.

50 Ibidem, s. 76 i 77.

${ }^{51}$ Po raz pierwszy terminu tego w odniesieniu do wyobrażeń osób niewidomych użył F. Hitschmann w roku 1892. Te specyficzne wyobrażenia nazwał surogatowymi, inaczej zastępczymi (niem. Surrogatvorstellungen). Jako jeden z pierwszych zwrócił uwagę na powstawanie wyobrażeń, które odnoszą się nie tylko do poznania zmysłowego u niewidomych, ale także do bogactwa określeń istniejących w języku ludzi widzących, z których korzystają niewidomi. Na podstawie przeprowadzonych przez siebie badań autor stwierdził, że tylko niewielka ilość słów, którymi posługuje się niewidomy, rzeczywiście zawiera adekwatne treści dotyczące wyobrażeń. Język ludzi widzących wykształcił się najpierw pod wpływem wyobrażeń, 
wisk i pojęć, których niewidomi nie są w stanie poznać za pomocą wzroku. Wyobrażenia surogatowe wraz z teorią zastępstwa zmysłów stanowią spójną koncepcję teoretyczną, której celem jest wyjaśnienie powstawania i funkcjonowania procesów poznawczych. W rozumieniu autorów tej teorii ${ }^{52}$ "mieć wyobrażenie” to znaczy mieć świadomość przedmiotu, który w danej chwili nie jest spostrzegany. Niewidomym niejednokrotnie zdarza się opisywać wyobrażenia przedmiotów czy zjawisk, których nigdy nie widzieli, a pojęcia te mają charakter werbalny, nie są poparte spostrzeżeniem wzrokowym. Badania na temat wyobrażeń surogatowych prowadziła m.in. Izabella Kucharczyk ${ }^{53}$ na grupie 63 uczniów niewidomych w klasach III i V szkoły podstawowej oraz I gimnazjum (i takiej samej widzącej grupie porównawczej). Wyobrażenia surogatowe podzieliła na dwie grupy - swoiste (jako typowe tylko dla niewidomych; 12 prób mających na celu określanie pojęć dotyczących kolorów, pojęć przestrzennych, zjawisk przyrodniczych, rozumienia pojęć zwierząt) i wspólne (dla niewidomych i widzących; 12 prób odnoszących się wyjaśnienia takich pojęć jak "yeti - człowiek śniegu”; "diabeł”; „anioł”; dobra wróżka”; "krasnoludek” czy „królewna Śnieżka”). Okazało się, że nie występują istotne statystycznie różnice między uczniami w poszczególnych klasach. Dostrzeżono prawidłowość, że im młodsi uczniowie, tym w zakresie swoistych wyobrażeń surogatowych formułują dłuższe wypowiedzi, a wraz z wiekiem są bardziej oszczędni w słowach. Podobną tendencję co do długości wypowiedzi dostrzeżono w zakresie wy-

w postaci znaku, symbolu, obrazka, natomiast wyobrażenia niewidomych kształtowane są na odwrót (na podstawie słowa tworzy się wyobrażenie danej osoby, rzeczy czy zjawiska). Określenia pochodzące z języka ludzi widzących stają się dla niewidomego pewnym „wytrychem”, który pozwala na zrozumienie nieznanych dotąd dla niego problemów.

${ }^{52}$ A. Beauvale, K. Klimasiński, Kształtowanie się pojęć abstrakcyjnych u dzieci niewidomych w wieku szkolnym. „Roczniki Komisji Nauk Pedagogicznych” 1980, t. XXVI, s. 133-146.

${ }^{53}$ I. Kucharczyk, Rozwój wyobrażeń surogatowych i rozumowania przez analogie. Niepublikowana praca doktorska, UMCS, Lublin 2009. 
obrażeń surogatowych wspólnych. Niewidomi trzecioklasiści udzielili dwa razy więcej wypowiedzi rozwiniętych niż piątoklasiści i gimnazjaliści. Można przypuszczać, że na taki wynik ma najprawdopodobniej wpływ ciekawość świata trzecioklasistów, ich otwartość i chęć podzielenia się swoją wiedzą. Z kolei starsi uczniowie wypowiadali się bardziej lapidarnie, formułowali definicje o ambicjach „naukowych”, unikając dygresji i kwiecistości wypowiedzi. Podobne wyniki świadczące o występowaniu wyobrażeń surogatowych u niewidomych i ich wpływie na rozwój zasobu słownictwa dziecka i rozumienia pojęć uzyskała Monika Jedynak ${ }^{54}$.

Do powstawania wyobrażeń surogatowych przyczynia się analogia. Z. Sękowska przypisuje jej duże znaczenie. Według niej analogia to „wszelkie podobieństwo między rzeczami pozwalające nam przypisywać jednej rzeczy cechy, o których wiemy, że przynależą drugiej"55. Analogia pozwala na łączenie ze sobą wrażeń, na szukaniu cech wspólnych. Taka aktywność poznawcza wzbogaca wiedzę, rozszerza zakres wyobrażeń surogatowych, które stają się w ten sposób wielomodalnymi. Na podstawie przeprowadzonych badań autorka wysunęła następujący wniosek: analogie osoby niewidome wykorzystują przy określaniu kształtu przedmiotu, jego wielkości, a także barwy. Rozwój wyobrażeń prowadzi także do wzrostu zasobu słownictwa. Im większy jest jego zasób, tym dzieciom łatwiej dokonywać operacji umysłowych, opisywać zjawiska i wyjaśniać pojęcia.

Badania na temat analogii semantycznych (w kategorii część całość; przeciwieństwa i przyczyna - skutek) i ich znaczenia dla niewidomych prowadzili m.in. Bogusław Pietrulewicz czy Izabella

${ }_{54}$ M. Jedynak, Wptyw nabywania języka pierwszego przez niewidome dzieci na nauke języka drugiego - implikacje dydaktyczne dla nauczycieli języków obcych, [w:] PLEJ_3 czyli PsychoLingwistyczne Eksploracje Jezykowe, red. O. Majchrzak, Wydawnictwo Uniwersytetu Łódzkiego, Łódź 2014; por. I. Kucharczyk, Wyobrażenia surogatowe jako jeden ze sposobów wyobrażania sobie świata przez niewidomych (komunikat z badań), [w:] Miejsce Innego we wspótczesnych naukach o wychowaniu. Wyzwania dla praktyki, red. I. Chrzanowska, B.Jachimczak, Wydawnictwo SANTORI, Łódź 2008.

55 Z. Sękowska, op. cit., s. 175. 
Kucharczyk $^{56}$. Analiza danych w zakresie rozumowania przez analogie semantyczne w kategorii część - całość pozwoliła odnotować różnice istotne statystycznie jedynie pomiędzy grupą uczniów niewidomych i widzących w wieku 14 lat, czyli uczęszczających do I klasy gimnazjum, na korzyść uczniów niewidomych. Pomiędzy pozostałymi grupami uczniów niewidomych i widzących nie zanotowano różnic istotnych statystycznie. W zakresie rozumowania przez analogie semantyczne $\mathrm{w}$ kategorii przeciwieństwa nie zarejestrowano różnic istotnych statystycznie pomiędzy uczniami niewidomymi a widzącymi. Ustalono, że istnieje istotna statystycznie różnica w zakresie rozumowania przez analogie w kategorii przyczyna - skutek pomiędzy uczniami niewidomymi a widzącymi w grupie uczniów 10-letnich (uczęszczających do klasy III szkoły podstawowej) na korzyść uczniów niewidomych. Błędy popełniane przez uczniów niewidomych i widzących, a dotyczące rozumowania przez analogie semantyczne, są bardzo podobne do siebie. Do najczęstszych, niezależnie od kategorii, należą: podawanie negacji zamiast wyrazu odnoszącego się do wymaganej relacji np. przeciwieństwa, perseweracje wyrazów, stosowanie synonimów i antonimów oraz przypadkowe skojarzenia.

Z badań prowadzonych w latach 70. XX w. przez Krzysztofa Klimasińskiego ${ }^{57}$ wynika, że dzieci z niepełnosprawnością wzroku mają trudności w rozumieniu relacji przestrzennych i związanych z nimi przyimkami (nad, pod, między, w, na prawo, na lewo, pomiędzy). Taka sytuacja może wynikać $z$ trudności w połączeniu znaczenia słowa i jego powiązania $\mathrm{z}$ położeniem przedmiotu. Tezę tę potwierdzają również badania Anne Dunlea i Elaine S. Andersen ${ }^{58}$

56 B. Pietrulewicz, Rozwój rozumienia niektórych relacji semantycznych u dzieci niewidomych w wieku szkolnym. [w:] Czynniki efektywności pracy pedagogicznej szkót dla uczniów niewidomych i niedowidzacych, red. Z. Sękowska, UMCS, Lublin 1978; I. Kucharczyk, op. cit. Badania przeprowadzone zostały na grupie 63 osób niewidomych (21 uczęszczało do klasy III szkoły podstawowej; 21 do klasy V szkoły podstawowej i 21 do klasy I gimnazjum). Grupa uczniów była komplementarna.

${ }^{57}$ K. Klimasiński, op. cit.

58 A. Dunlea, E.S. Andersen, The emergence proces: conceptual and linguistic influences on morphological development, “First Language" 1992, 12, s. 95-115. 
z 1992 r.), którzy są przekonani, że dzieci niewidome rzadziej stosują liczbę mnogą, czasowniki w 3. osobie oraz przyimki. W grupie tej obserwuje się również późniejsze używanie zaimków osobowych i dzierżawczych, a także zamianę osoby 1. z 2. czasownika.

Cechą, która na pewno nie wpływa pozytywnie na rozwój mowy, są pojawiające się i często utrwalane wady wymowy. Najczęstsze błędy dotyczą wypowiadania głosek wargowych, wargowozębowych, syczących, szumiących i głoski "r". Najprawdopodobniej dzieje się tak, gdyż niewidomi od momentu urodzenia nie mają odpowiedniego wzorca i możliwości korygowania w wyniku obserwacji aparatu artykulacyjnego.

\section{Podsumowanie}

W artykule tym opisano wybrane, ale najważniejsze aspekty rozwoju języka u dzieci niewidomych. Skoncentrowano się na początkowym etapie i czynnikach mających wpływ na występujące trudności w zakresie rozwoju języka i mowy. W przypadku grupy osób z niepełnosprawnością wzrokową czynników tych jest dość sporo. Występujące szumy $w$ interakcji społecznej, nieprawidłowo użyte słowa, brak poznania przedmiotu, niezrozumienie znaczenia pojęcie powoduje, że dziecko nie jest $\mathrm{w}$ stanie wyrazić swoich potrzeb, pragnień czy marzeń za pomocą języka.

Mimo że badań na ten temat jest stosunkowo niewiele, nie oznacza, że naukowcy nie zajmują się tym zagadnieniem i nie podkreślają relacji, jaka zachodzi między wzrokiem a rozwojem języka. W literaturze przedmiotu można odnaleźć informacje z badań mówiących zarówno o występujących opóźnieniach, jak i prawidłowym rozwoju mowy u dzieci niewidomych.

W oparciu o analizę literatury przedmiotu nie da się jednoznacznie określić, jaka ta specyfika rozwoju językowego jest. Wynika to stąd, że badania są zazwyczaj prowadzone na bardzo małych grupach, co powoduje, że wnioski są niejednokrotnie sprzeczne. Zarówno w literaturze polskiej, jak i anglojęzycznej nie ma cało- 
ściowych badań na temat rozwoju mowy i języka w tej populacji w całym kraju. Nadal nie ma odpowiedzi na nurtujące badawczy pytania. Dlatego też należałoby przeprowadzić na szeroko zakrojoną skalę badania dotyczące rozwoju mowy $\mathrm{u}$ dzieci $\mathrm{z}$ niepełnosprawnością wzroku, uwzględniając zarówno rozwój słownictwa, jak i aspektów dotyczących pragmatyki, syntaktyki, morfologii oraz produkcji dźwięków.

\section{Bibliografia}

Aronson E., Wilson T.D., Akert R.M., Psychologia społeczna. Serce i umyst, Wydawnictwo PWN, Warszawa 2000.

Bedny M., Dodell-Feder D., Pascual-Leone A., Fedorenko E., Language processing in the occipital cortex of congenitally blind, "Proceedings of the National Academy of Sciences" 2011, nr 15, 108 (11).

Bendych E., Janik M., Nauczanie początkowe dzieci niewidomych, Wydawnictwo PWN Warszawa 1981.

Beauvale A., K. Klimasiński, Ksztattowanie się pojęć abstrakcyjnych u dzieci niewidomych w wieku szkolnym, „Roczniki Komisji Nauk Pedagogicznych” 1980 t. XXVI.

Bigelow A., Blindness. In B. Hopkins. The Cambridge encyclopedia of child development, Cambridge University Press, New York 2005.

Bocus B., Shugar G.W., Psychologia języka dziecka. Osiagnięcia, nowe perspektywy. Wydawnictwo GWP, Gdańsk 2007.

Brambring M., Divergent Development of Verbal Skills in Children Who Are Blind or Sighted, "Journal of Visual Impairment and Blindnes" 2007.

Brambring M., Divergente Entwicklung blinder und sehender Kinder in vier Entwicklungsbereichen [Divergent development in children who are blind or sighted: Four developmental domains], "Zeitschrif für Entwicklungspsychologie und Päddagogische Psychologie" 2005, nr 37.

Brambring M., Sprachentwicklung blinder Kinder [Language development in children who are blind], [w:] Psycholinguistik: Ein internationales Handbuch, red. G. Rickheit, T. Herrmann, W. Deutsch, de Gruyter, Berlin 2005.

Campbell J., Maternal directives to young children who are blind, "Journal of Visual Impairment and Blindness" 2003, 91.

Ciccarelli S.K., White J.N., Psychologia, Dom Wydawniczy Rebis, Poznań 2015.

Cieszyńska J., Metoda Krakowska wobec zaburzeń rozwoju dzieci. Z perspektywy fenomenologii, neurobiologii i językoznawstwa, Wydawnictwo Centrum Metody Krakowskiej, Kraków 2013. 
Chomsky N., Zagadnienia teorii składni, Zakład Narodowy Ossolińskich, Wrocław, Warszawa, Kraków, Gdańsk, Łódź 1982.

Conti-Ramsden G., Perez-Pereira M., Conversational interactions between mothers and their infants who are congenitally blind, have low vision, or are sighted, "Journal of Visual Impairment and Blindness" 1999, 93.

Dorobek-Ostrowska B., Podstawy komunikowania spotecznego, Wydawnictwo ASTRUM, Wrocław 2004.

Dote-Kwan T, Hughes M., The home environments of young blind children, "Journal of Visual Impairment and Blindness" 1994, Nr 88, s. 31-42.

Dunlea A., Andersen E.S., The emergence proces: conceptual and linguistic influences on morphological development, "First Language" 1992, 12.

Eliot L., Co tam się dzieje. Jak rozwijać mózg $i$ umyst w pierwszych latach życia, Wydawnictwo Media Rodzina, Warszawa 2010.

Freiberg S., Insights from the blind: Comparative studies of blind and sighted infants, New American Library, New York 1977.

Fiske J., Wprowadzenie do badań nad komunikowaniem, Wydawnictwo ASTRUM, Wrocław 1999.

Gałkowski T., Trudności rozwojowe u dzieci niewidomych w okresie niemowlęcym, „Przegląd Tyflologiczny" 1975, Nr 1/3.

Głodkowski W., Komunikowanie interpersonalne, Hansa Communication, Warszawa 2006.

Goban-Klas T., Media $i$ komunikowanie masowe. Teorie $i$ analizy prasy, radia, telewizji i Internetu, Wydawnictwo PWN, Warszawa 2001.

Górska T., Grabowska A., Zagrodzka J., Mózg a zachowanie, Wydawnictwo PWN, Warszawa 2000.

Harwas-Napierała B., Trempała J., Psychologia rozwoju człowiek. Charakterystyka okresów życia człowieka, Wydawnictwo PWN, Warszawa 2001.

Hatton D.D., Bailey D.B., Burchinal M.R., Ferrell K.A., Development growth curves of preschool children with vision impairments, "Child Development" 1997, nr 68.

Hobson R.P., Bishop M., The pathogenesis of autism: Insights from congenital blindness. "Philosophical Transactions of the Royal Society of London Series B Biological Sciences" 2003, Nr 358.

Jacobson R., W poszukiwaniu istoty jezzka, Wydawnictwo PIW, Warszawa 1989.

Jaworska-Biskup K., Language acquisition in the blind child, Wydawnictwo KUL, Lublin 2011.

Jedynak, Wptyw nabywania języka pierwszego przez niewidome dzieci na nauke języka drugiego - implikacje dydaktyczne dla nauczycieli jezzyków obcych, [w:] PLEJ_3 czyli PsychoLingwistyczne Eksploracje Jezzykowe, red. O. Majchrzak, Wydawnictwo Uniwersytetu Łódzkiego, Łódź 2014.

Kaczorowska-Bray K., Milewski S., Wczesna interwencja logopedyczna, Wydawnictwo HARMONIA, Gdańsk 2016. 
Kekelis L.S., Prinz P.M., Blind and sighted children with their mothers: The development of discourse skills, "Journal of Visual Impairment and Blindness" 1996, nr 90.

Klimasiński K., Rola wyobrażeń przestrzennych w rozwoju myślenia dzieci niewidomych, PAN, Zakład Narodowy Ossolińskich, Wrocław - Warszawa - Kraków Gdańsk 1989.

Knapp M.L., Hall J.A., Komunikacja niewerbalna w interakcjach międzyludzkich. Wydawnictwo ASTRUM, Wrocław 2000.

Konarska J., Rozwój i wychowanie rehabilitujące dziecka niewidzącego w okresie wczesnego i średniego dzieciństwa, Wydawnictwo UP, Kraków 2010.

Kucharczyk I. Rozwój wyobrażeń surogatowych i rozumowania przez analogie, niepublikowana praca doktorska, UMCS, Lublin 2009.

Kulczycki E., Teoretyzowanie komunikacji, Wydawnictwo Naukowe Instytutu Filozofii UAM, Poznań 2012.

Majewski T., Tyflopsychologia rozwojowa. Psychologia dzieci niewidomych i stabo widzacych, Polski Związek Niewidomych, Warszawa 2002.

Mikołajczak-Matyja N., Definicje formułowane przez niewidomych i widzacych jako przyczynek do rozważań nad zjawiskiem werbalizmu, „Szkoła Specjalna” 2011, nr 5.

Mikołajczak-Matyja N., Hierarchiczna struktura leksykonu umysłowego. Relacje semantyczne w leksykonie widzących i niewidomych użytkowników języka, Wydawnictwo Naukowe UAM, Poznań 2008.

Milewski S., Kaczorowska-Bray K., Logopedyczne aspekty przyswajania języka przez dzieci niewidome, „Poradnik Językowy” 2015, nr 5.

Orkan-Łęcka M., Mama, tata, dziecko czyli o tym, jak uczyć mate niewidome dziecko w warunkach domowych, „Materiały Tyflologiczne” 2003, nr 14.

Pérez-Pereira M., Análisis pragmático de las conversaciones entre niños ciegos y sus madres y la cuestión de la directividad maternal /Pragmatic analysis of conversations between blind children and their mothers and the issue of maternal directivity, "Infancia y Aprendizaje" 2008, nr 31(4).

Perez-Pereira M., Language Development in Blind Children, [w:] Encyclopedia of Language and Linguistics, t. 6, red. K. Brown, Pergamon, Oxford 2000.

Pietrulewicz B., Rozwój rozumienia niektórych relacji semantycznych u dzieci niewidomych w wieku szkolnym, [w:] Czynniki efektywności pracy pedagogicznej szkót dla uczniów niewidomych i niedowidzacych, red. Z. Sękowska, UMCS, Lublin 1978.

Porayski-Pomsta J., O rozwoju mowy dziecka. Dwa stadia, Dom Wydawczy ELIPSA Warszawa 2015.

Porayski-Pomsta J., Umiejętności komunikacyjne i językowe dzieci w wieku przedszkolnym, Wydawnictwo UW, Warszawa 1993.

Preisler G., Communicative Development in Young Blind Children, [w:] Communcative Development, red. G. Conti-Ramsden, C. Snow, Cambridge University Press, Cambridge 1990. 
Preisler G.M., Early patterns of interaction between blind infants and their sighted mothers, "Child: Care, Health and Development" 1991, nr 17.

Rocławki B., Kształtowanie komunikacyjnych postaw u dzieci w wieku niemowlęcym, [w:] Opieka logopedyczna od poczęcia, red. B. Rocławski, Wydawnictwo UG, Gdańsk 1989.

Rogow S.M., Communication and language: Issues and concerns, [w:] The Lighthouse handbook on vision impairment and vision rehabilitation, Vol. 1, red. B. Silverstone, M.A. Lang, B.P. Rosenthal, E.E. Faye, Oxford University Press, New York 2000.

Sameroff A.J., Fiese B.H., Transactional regulation: The developmental ecology of early intervention, [w:] Handbook of early childhood intervention, red. J.P. Shonkoff, S.J. Meisels, Cambridge University Press, Cambridge 2000.

Sękowska Z., Kształcenie dzieci niewidomych, Wydawnictwo PWN, Warszawa 1974.

Schaffer D.R., Kipp K., Psychologia rozwoju. Od dziecka do dorostości, Wydawnictwo Harmonia, Gdańsk 2015.

Tadić V., Pring L., Dale N., Are language and social communication intact in children with congenital visual impairment at school age?, "Child Psychology and Psychiatry" 2010, Nr 51.

Walsch K., Neuropsychologia kliniczna, Wydawnictwo PWN, Warszawa 2000.

Warren D.H., Blindness and early childhood development, American Foundation for the Blind, Inc. New York 1977.

Vinter A., Fernandes V., Orlandi O., Morgan P., Verbal definitions of familiar objects in blind children reflect their peculiar perceptual experience, Child: care, health and development" 2012, nr 39(6).

Zaorska M., Tyflologopedia jako subdyscyplina szczegótowa logopedii oraz element jej współczesnej koncepcji strukturalnej, „Przegląd Badań Edukacyjnych” 2016, nr 1 (22).

Zaorska M., Istota i szczególność zaburzeń mowy oraz terapii logopedycznej dzieci z niepetnosprawnością wzrokowa, „Forum Logopedy” 2015, nr 7. 